\title{
Evaluation of Local Trichoderma Isolates against Potential Soil Borne Pathogens of Pulses
}

\author{
A.G. Panda*, M. K. Mishra, S. K. Beura and B. Boblina \\ Department of Plant Pathology, College of Agriculture, Orissa University of Agriculture and \\ Technology, Bhubaneswar, Odisha-751003, India \\ *Corresponding author
}

\section{A B S T R A C T}

\begin{tabular}{|l|}
\hline $\begin{array}{l}\text { Ke y w o r d s } \\
\text { Fusarium } \\
\text { oxysporum, } \\
\text { Crown rot, } \\
\text { Aspergillus flavus }\end{array}$ \\
\hline Article Info \\
\hline $\begin{array}{l}\text { Accepted: } \\
\text { 24 August } 2019 \\
\text { Available Online: } \\
\text { 10 September } 2019\end{array}$
\end{tabular}

\section{Introduction}

Pulse play a significant role in Indian Agriculture as they are accounted for proteinrich human dietIndia accounts for over one third of the total world area and over 20 per cent of total world production in pulse. The major fungal diseases which infect pulses are Wilt (Fusarium oxysporum), Dry root rot (Rhizoctonia bataticola), Collar rot
(Sclerotium rolfsii), Wet root rot (Rhizoctonia solani), Ascochyta blight (Ascochyta rabiei), Botrytis grey mould (Botrytis cinerea), Black root rot (Fusarium solani), Seed rot (Aspergillus flavus), Stem rot (Sclerotinia sclerotiorum), Crown rot (Sclerotium rolfsii), Foot rot (Phacidiopycnis padwickii), Sclerotinia wilt (Sclerotinia sclerotiorum).Fungal based BCAs have gained wide acceptance next to bacteria (mainly, 
Bacillus thuringiensis), primarily because of their broad spectrum in terms of disease control and yield increase (Copping et al., 2000). In this context, Trichoderma spp. have been the cynosure of many researchers who have been contributing to biological control pursuit through use of fungi (Ahmad et al., 1987 and Aziz et al., 1997). Furthermore, Trichoderma spp. share almost $50 \%$ of fungal BCAs market, mostly as soil/growth enhancers and this makes them interesting candidates to investigate (Whipps et al., 2001).According to Punja and Utkhede (2003), Trichoderma spp. are the most widely studied mycoparasitic fungi. In addition to the well-recognized mycoparasitic nature of Trichoderma fungi, induction of resistance against pathogens in plants has also been reported by Benhamou, (1999).

The following studies have been done for the purpose:

In view of the above context local Trichoderma isolates were collected from different crop rhizospheres from OUAT fields.

Also two major soil borne pathogens were isolated and identified from wilted green gram plants.

The biocontrol potential of the Trichoderma isolates were evaluated both in vitro and in vivo against two soil borne pathogens from green gram.

\section{Materials and Methods}

Soil samples from rhizospheres of different crops like groundnut, paddy (Agronomy field OUAT) tomato (Vegetable improvement project, Central farm, OUAT), Brinjal (Trial fields of department of Plant Pathology, College of Agriculture, OUAT). Other isolates were collected from banana fruit and IIHR, Bangalore. The serial dilution plate technique as mentioned below was followed for isolation. Each dilution was transferred aseptically into a sterilized petriplates.

Then different colonies of Trichoderma $s p$.were selected and subcultured in PDA plates by hyphal tip method. Development of Trichoderma colonies on PDA were observed from second day till two weeks. Trichoderma colonies were observed under the microscope and sub-cultured on PDA at $28 \pm 1{ }^{\circ} \mathrm{C}$ for two weeks. Morphological observations like colony colour, type and growth of colony, macroscopic criteria: mycelium appearance, conidiation colour, pattern, abundance or absence, and coloration of the medium were recorded for the isolates grown on PDA. Entire mycelia and colony growth were observed under Compound Microscope. Isolates of Trichoderma spp. were grouped according to literatures on Trichoderma spp. Diseased plants of mungbean showing characteristic symptoms of root rot (Rhizoctonia sp.) and wilt (Fusariumsp were collected from experimental area of OUAT.The samples were cut into small pieces and surface sterilized with 1:1000 mercuric chloride $\left(\mathrm{HgCl}_{2}\right)$ for 30 seconds followed by repeated washing with sterilized water before keeping them on Petri plate containing PDA. Growing colony was identified under research microscopic. Pure culture was prepared following hyphal tip method.

The efficacy of Trichoderma isolateswere tested against the pathogens by dual culture technique maintaining three replications. The efficacy of Trichoderma isolateswere expressed as percentage inhibition of mycelia growth over control. The Percent inhibition over control was calculated according to formula:

$\mathrm{I}=\frac{\mathrm{C}-\mathrm{T}}{\mathrm{C}} \times 100$

$\mathrm{I}=$ Percent inhibition 
$\mathrm{C}=$ Radial growth in control

$\mathrm{T}=$ Radial growth in treatment

The data obtained in-vitro on per cent growth inhibition of test fungus were analysed following Completely Randomized Design (CRD).Good sandy loam to loam type soil was collected from the field and autoclaved twice at $121^{\circ} \mathrm{C}$ temperature for $15 \mathrm{lbsp} . s . i$. for 20 minutes and put in small polypropylene bags according to the number of treatments and replications. Fresh active culture of the pathogens prepared in PDA were mixed with soil in each polybags. They were then left for incubation for one day. Good quality mungbean seeds were collected and presoaked for 4 to 6 hours. After one day of incubation of the polybags the seeds were sown in the polybags @ 10 seeds/polybag. Two best isolates of Trichoderma were taken to test against soil borne pathogens. After the mungbeen seedlings reached two stage the active culture of Trichoderma isolates were mixed with the soil in the rhizosphere zone. Three replications for each treatment was maintained.

\section{Results and Discussion}

A total seven number of Trichoderma isolates were collected from different crop rhizospheres and individual colony characters, mycelial structures, presence of phialides and conidial size were studied vividly in the current study. Dull white fluffy growth of the mycelium was found in Isolate 1 and also it was highly sporulating. Faint greenish sporulation was found in Isolate 2 with white radiating cottony mycelia. Whitish mycelial growth was also found in Isolate 3 with greenish sporulation at the centre. Dense mycelial growth with radial manner and faint greenish colour of the mycelia was found in Isolate 4. Greenish colouration of the petriplates and sporulation with white to dull white nature were found in Isolate 5, Isolate 6 and Isolate 7. On the basis of colony characters, colour and growth behaviour, the isolate were confirmed as Trichodermasp. (Figure-1). Druzhinina and Kubicek (2005) extensively reviewed the species concept of Trichoderma fungi and gave the view of difficulty to distinguish morphologically species of Trichoderma. Two pathogens i.e Rhioctonia sp. and Fusarium sp. were isolated from the root region of green gram. In case of Rhizoctonia sp. the mycelial growth of the fungus was radiating sparse after 7 days. Red to orange red coloured rounded sclerotia were found towards the periphery of the plate after 7 days.

The mycelium was both intra and intercellular. Hyphae were septate, thick walled. Sclerotia were abundantly found. The results supported the findings of Vijayan and Nair, 1985. In case of Fusarium $s p$. mycelium was extensive, hyphae were septate branched both inter and intracellular. Mycelium became pink to orange coloured at maturity. Conidia were found with slight bend at the middle with rounded ends and mostly two celledwhich is supported by the findings of Burgess et al., 1994.

In Table-1 Figure-2, Highest percentage inhibition (56.04\%) against Rhizoctonia sp. was observed by Trichoderma Isolate 5 followed by Trichoderma Isolate $2(54.20 \%)$, Isolate 7 was found to be the least effective in controlling Rhizoctonia sp.Then same trend was also observed for Isolate 5 inhibiting maximum mycelial growth $(70.1 \%)$ against Fusarium sp followed by Isolate $2(69.1 \%$ inhibition) (Table 1, Figure-2).

The lowest growth inhibition was observed in Isolate 7 (56.5\%) against Fusarium sp. Bansode et al., (2011) screened eight isolates of Trichoderma spp for antagonistic effect against Sclerotium roilfsii and Rhizoctonia solani. Kumar et al., (2007) tested three species of Trichoderma i.e. T. virens and $T$. viride and T.harzianum against $F$. oxysporum f.sp subglutinans and found all effective. 
Trichoderma Isolate 5 increased $84.08 \%$ seedling length of green gram plants where Fusarium sp. was pre-inoculated and Isolate 2 increased $75.9 \%$ seedling length where Rhizoctonia sp. was pre-inoculated (Table-2). It indicated greater efficacy of Tr. Isolate 5 against Fusarium sp. when applied as soil inoculation method than Isolate 2. Deshmukh and Raut (1992), Hussain et al., (1990) reported efficacy of $T$. harzianum against R.solani of mungbean.

Table.1 In vitro efficacy of Trichoderma isolates against Rhizoctonia sp. and Fusarium sp.

\begin{tabular}{|c|c|c|c|c|c|}
\hline \multirow[t]{3}{*}{ Serial No. } & \multirow[t]{3}{*}{ Isolates } & \multicolumn{4}{|c|}{ Soil Borne Pathogen } \\
\hline & & \multicolumn{2}{|c|}{ Rhizoctonia sp. } & \multicolumn{2}{|l|}{ Fusarium sp. } \\
\hline & & $\begin{array}{l}\text { Mean radial } \\
\operatorname{growth}(\mathbf{m m})\end{array}$ & $\begin{array}{l}\% \text { Inhibition } \\
\text { of mycelial } \\
\text { growth }\end{array}$ & $\begin{array}{l}\text { Mean radial } \\
\operatorname{growth}(\mathbf{m m})\end{array}$ & $\begin{array}{l}\% \text { Inhibition } \\
\text { of mycelial } \\
\text { growth }\end{array}$ \\
\hline 1. & Isolate 1 & 48.00 & 32.60 & 17.80 & 59.3 \\
\hline 2. & Isolate 2 & 32.70 & 54.20 & 13.60 & 69.1 \\
\hline 3. & Isolate 3 & 47.30 & 33.70 & 16.60 & 62.2 \\
\hline 4. & Isolate 4 & 39.40 & 44.70 & 14.10 & 67.9 \\
\hline 5. & Isolate 5 & 31.10 & 56.40 & 13.10 & 70.1 \\
\hline 6. & Isolate 6 & 33.30 & 53.30 & 18.10 & 58.7 \\
\hline 7. & Isolate 7 & 51.60 & 27.60 & 19.10 & 56.5 \\
\hline 8. & Control & 71.30 & & 43.90 & \\
\hline \multicolumn{2}{|l|}{$\mathrm{SE}(\mathrm{m})+/-$} & 0.76 & & 0.84 & \\
\hline \multicolumn{2}{|l|}{ C.D. $(5 \%)$} & 2.30 & & 2.55 & \\
\hline
\end{tabular}

Table.2 Effect of soil application with Trichoderma isolates on seedling length of green gram plant inoculated with different soil borne pathogen

\begin{tabular}{|l|l|c|c|c|c|}
\hline Serial & Isolates & \multicolumn{2}{|c|}{ Rhizoctonia sp. } & \multicolumn{2}{|c|}{ Fusarium sp. } \\
\cline { 3 - 6 } No. & $\begin{array}{c}\text { Mean } \\
\text { seedling } \\
\text { length }(\mathbf{m m})\end{array}$ & $\begin{array}{c}\text { \%increase } \\
\text { over control }\end{array}$ & $\begin{array}{c}\text { Mean } \\
\text { seedling } \\
\text { length }(\mathbf{m m})\end{array}$ & $\begin{array}{c}\text { \% increase } \\
\text { over control }\end{array}$ \\
\hline $\mathbf{1 .}$ & $\begin{array}{l}\text { Trichoderma } \\
\text { Isolate 2 }\end{array}$ & 14.43 & 75.97 & 13.57 & 75.55 \\
\hline 2. & $\begin{array}{l}\text { Trichoderma } \\
\text { Isolate 5 }\end{array}$ & 14.36 & 75.12 & 14.23 & 84.08 \\
\hline 3. & Control & 8.20 & & 7.73 & \\
\hline
\end{tabular}


Int.J.Curr.Microbiol.App.Sci (2019) 8(9): 2499-2505

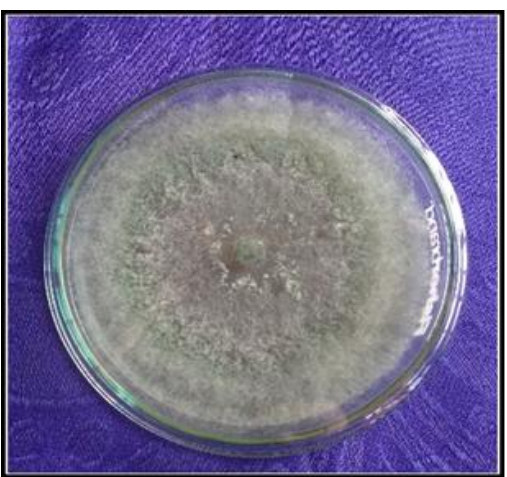

(a) Isolate 1

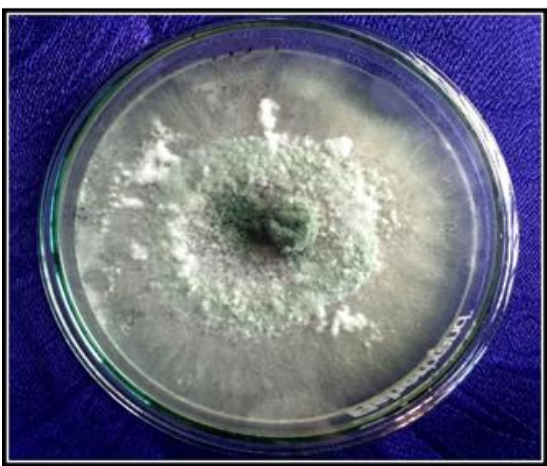

(c) Isolate 3

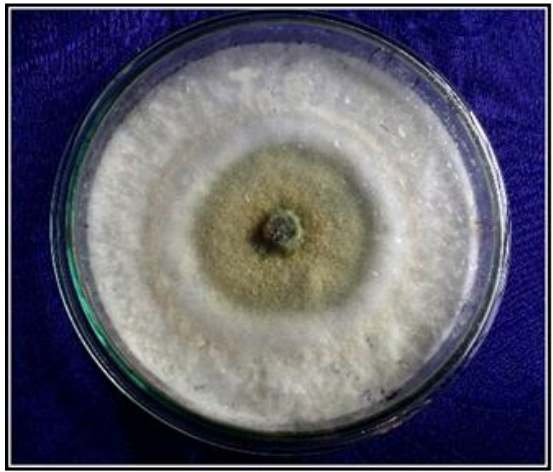

(e) Isolate 5

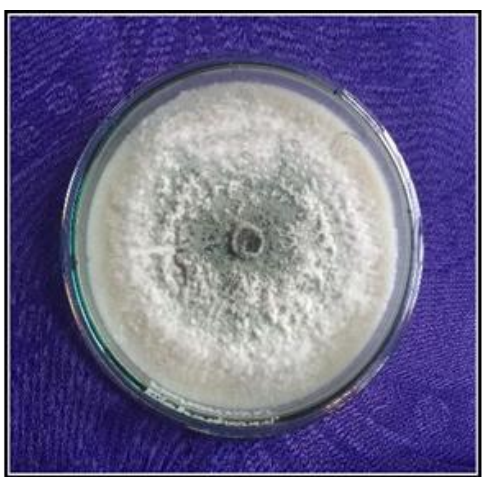

(b) Isolate 2

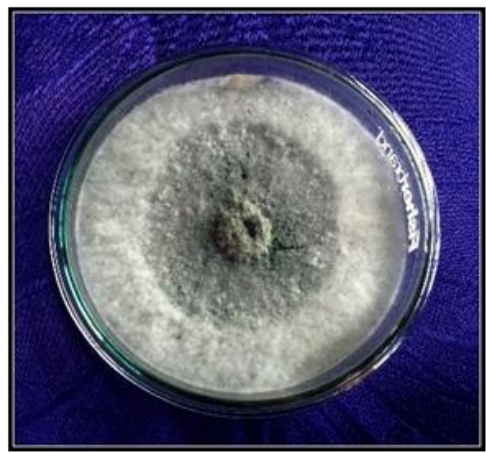

(d) Isolate 4

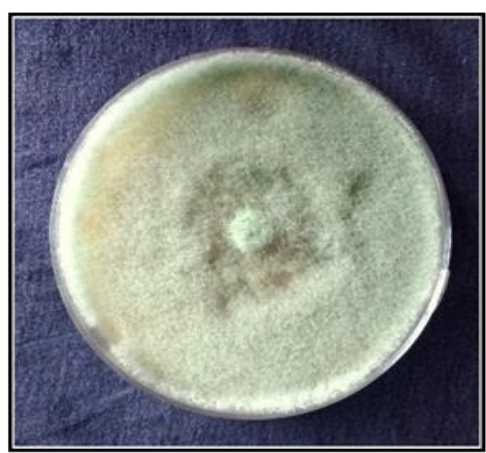

(f) Isolate 6

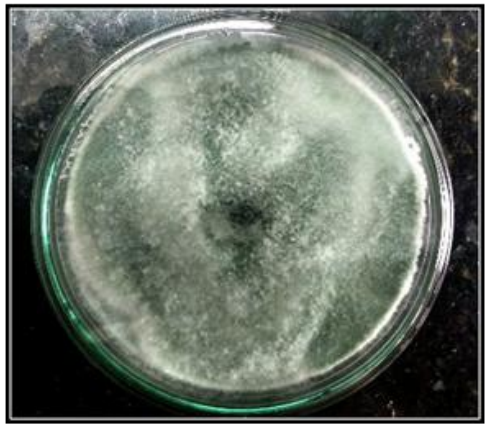

(g) Isolate 7( T. harzianum, IIHR )

Figure 1. Pure cultures of different Trichoderma isolates in PDA. 

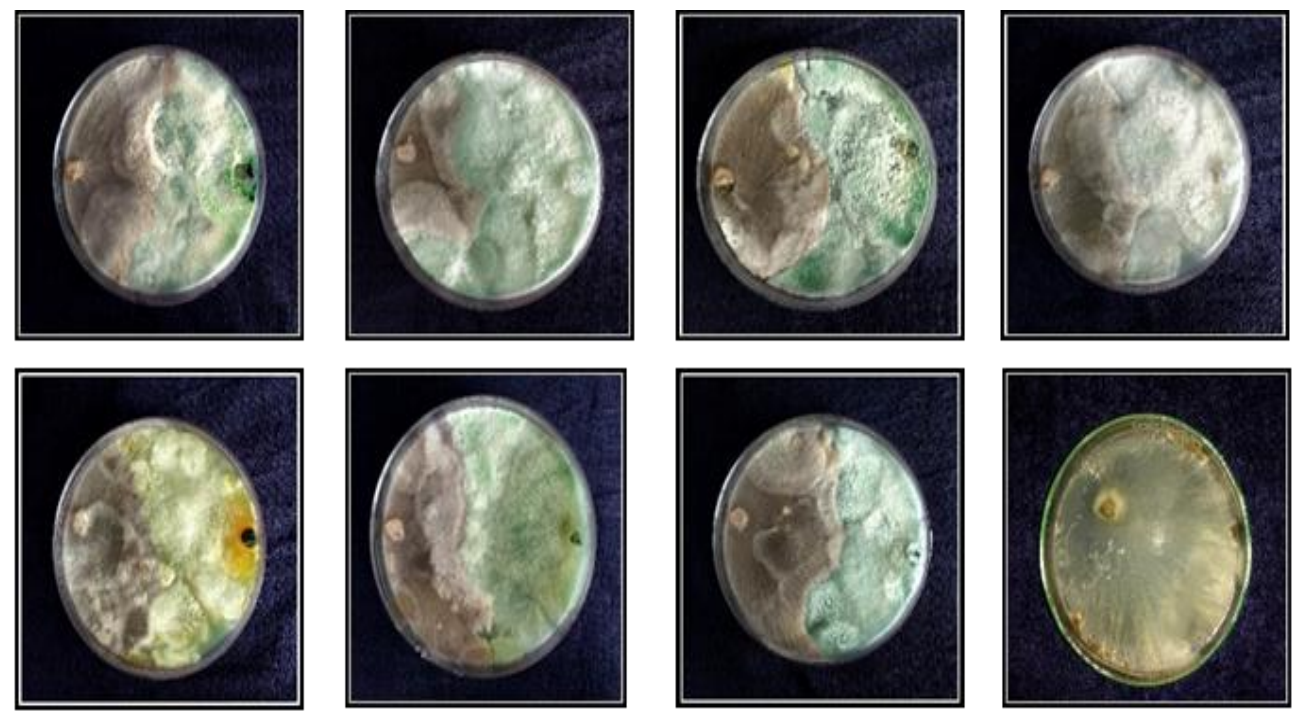

(a) Rhizoctonia sp.
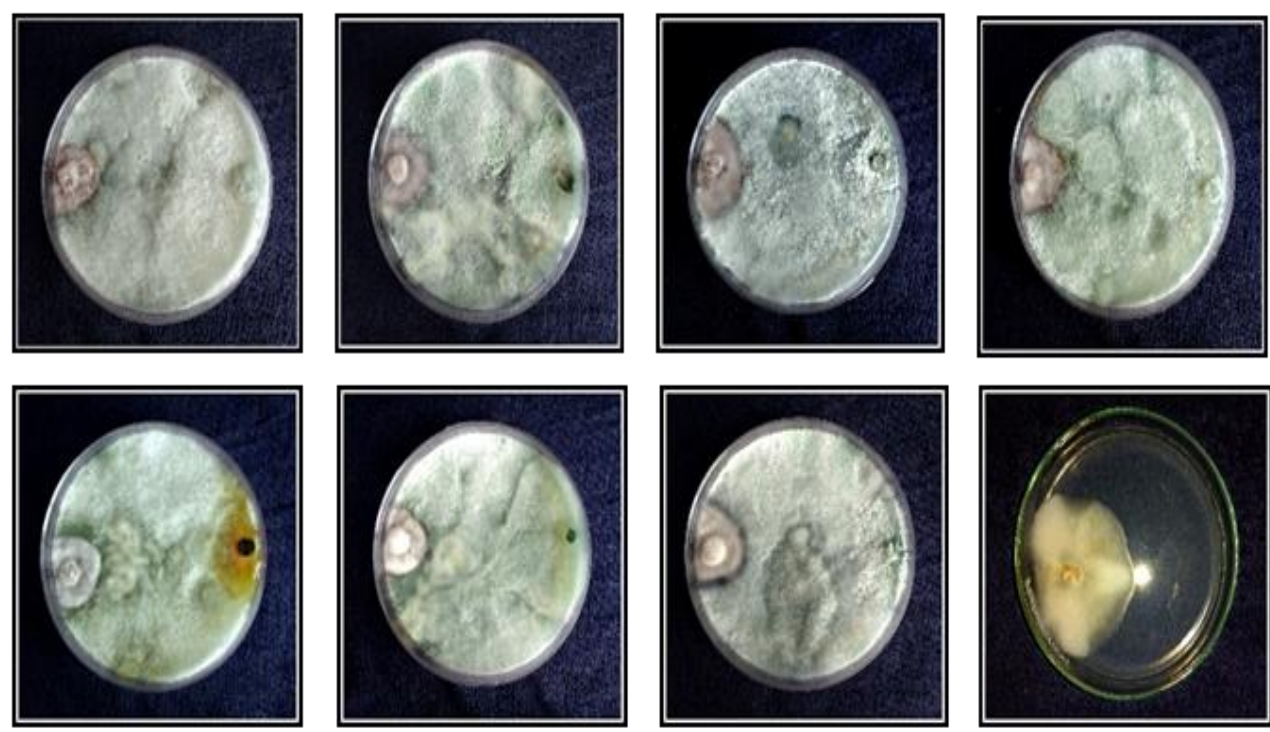

(a) Fusarium sp

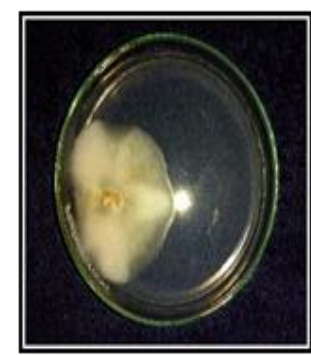

T1: Isolate 1

T2: Isolate 2

Figure 2. Efficacy of Trichoderma isolates against Rhizoctonia sp.\& Fusarium sp. in vitro

T3: Isolate 3

T4: Isolate 4 T5: Isolate 5 T6: Isolate 6 T7: Isolate 7 T8: Control 


\section{References}

Ahmad JS and Baker R. 1987. Competitive saprophytic ability and cellulolytic activity of rhizosphere-competent mutants of Trichoderma harzianum, Phytopathology77: 358-362.

Aziz NH, El-Fouly MZ, El-Essawy AA and Khalaf MA. 1997. Influence of bean seedling root exudates on the rhizosphere colonization by Trichoderma lignorum for the control of Rhizoctonia solani, Botanical Bulletin AcademiaSinica, 38: 33-39.

Benhamou N, Rey P, Picard K and Tirilly Y. 1999. Ultrastructural and cytochemical aspects of the interaction between the mycoparasite Pythium oligandrum, and soilborne plant pathogens, Phytopathology89: 506517.

Burgess LW, Summerell BA, Bullock S, Gott KP. 1994. Backhouse D. Laboratory manual for Fusarium research, pp. 116-117, Sydney: University of Sydney.

Copping LG and Menn JJ. 2000. Biopesticides: a review of their action, applications and efficacy, Pest Management Science56: 651-676.
Druzhinina IS and Kubicek CP. 2005. Species concepts and biodiversity in Trichoderma and Hypocrea: from aggregate species to species clusters, Journal ofZhejiang University Science, 6: 100-112.

Kumar B and Dubey SC. 2007. Effect of media, temperature and $\mathrm{pH}$ on growth and sporulation of Colletotrichum dematiumvar truncate. Annual. Plant. Protection. Science., 15: 260-261.

Punja ZK and Utkhede RS. 2003. Using fungi and yeasts to manage vegetable crop diseases, Trends in Biotechnology,21: 400-407.

Vijayan M and Nair CM. 1985. Anastomosis grouping of isolates of Rhizoctonia solani Kuhn (Thanatephorus cucumeris, (Frank Donk) causing sheath blight of rice. Current Science, 54: 289-291.

Whipps JM and Lumsden RD. 2001. Commercial use of fungi as plant disease biological control agents: status and prospects, Fungal Biocontrol Agents: Progress, Problems and Potential, Butt T, Jackson C and Magan N (Eds.), pp 9-22, CABI Publishing, Wallingford.

\section{How to cite this article:}

Panda, A. G., M. K. Mishra, S. K. Beura and Boblina, B. 2019. Evaluation of Local Trichoderma Isolates against Potential Soil Borne Pathogens of Pulses. Int.J.Curr.Microbiol.App.Sci. 8(09): 2499-2505. doi: https://doi.org/10.20546/ijcmas.2019.809.290 